\title{
The Role of Tyrosine Phosphorylation of Protein Kinase C Delta in Infection and Inflammation
}

\author{
Qingliang Yang ${ }^{1,+}$, Jordan C. Langston ${ }^{2,+}$, Yuan Tang ${ }^{1}$, Mohammad F. Kiani ${ }^{1,3}$ and \\ Laurie E. Kilpatrick 4,*(D) \\ 1 Department of Mechanical Engineering, College of Engineering, Temple University, Philadelphia, PA 19122, \\ USA; tug44932@temple.edu (Q.Y.); tud19329@temple.edu (Y.T.); mkiani@temple.edu (M.F.K.) \\ 2 Department of Bioengineering, College of Engineering, Temple University, Philadelphia, PA 19122, USA; \\ tuj27061@temple.edu \\ 3 Department of Radiation Oncology, Lewis Katz School of Medicine, Temple University, Philadelphia, \\ PA 19140, USA \\ 4 Center for Inflammation, Clinical and Translational Lung Research, Department of Thoracic Medicine and \\ Surgery, Lewis Katz School of Medicine, Temple University, Philadelphia, PA 19140, USA \\ * Correspondence: laurie.kilpatrick@temple.edu; Tel.: +1-(215)-707-8420 \\ + These authors contributed equally to this work.
}

Received: 7 March 2019; Accepted: 22 March 2019; Published: 26 March 2019

check for updates

\begin{abstract}
Protein Kinase C (PKC) is a family composed of phospholipid-dependent serine/threonine kinases that are master regulators of inflammatory signaling. The activity of different PKCs is context-sensitive and these kinases can be positive or negative regulators of signaling pathways. The delta isoform $(\mathrm{PKC} \delta)$ is a critical regulator of the inflammatory response in cancer, diabetes, ischemic heart disease, and neurodegenerative diseases. Recent studies implicate PKC $\delta$ as an important regulator of the inflammatory response in sepsis. PKC $\delta$, unlike other members of the PKC family, is unique in its regulation by tyrosine phosphorylation, activation mechanisms, and multiple subcellular targets. Inhibition of PKC $\delta$ may offer a unique therapeutic approach in sepsis by targeting neutrophil-endothelial cell interactions. In this review, we will describe the overall structure and function of PKCs, with a focus on the specific phosphorylation sites of PKC $\delta$ that determine its critical role in cell signaling in inflammatory diseases such as sepsis. Current genetic and pharmacological tools, as well as in vivo models, that are used to examine the role of PKC $\delta$ in inflammation and sepsis are presented and the current state of emerging tools such as microfluidic assays in these studies is described.
\end{abstract}

Keywords: PKC; PKC $\delta$; phosphorylation; microfluidics; inflammation; sepsis

\section{Protein Kinase C (PKC) Superfamily}

Protein Kinase C (PKC) was first identified by Nishizuka and coworkers in 1977 and is now known to be composed of a family of phospholipid-dependent serine/threonine kinases [1]. PKC isoforms (PKCs) are involved in numerous signal transduction pathways and are implicated in the regulation of numerous cellular functions [2-4]. These kinases are composed of a highly conserved catalytic domain (C-terminus) and a regulatory domain (N-terminus) that demonstrates considerable variability across family members [2]. Based on structural elements and cofactor requirements, mammalian PKCs are classified into four broad categories comprising classical PKCs (cPKCs: $\alpha, \beta-\mathrm{I}, \beta-\mathrm{II}$, and $\gamma$ isoforms), novel PKCs (nPKCs: $\delta, \varepsilon, \eta$, and $\theta$ isoforms), atypical PKCs (aPKCs: $\iota$ and $\zeta$ isoforms), and PKC-related kinases (PRKs 1-3) [2-7]. Calcium $\left(\mathrm{Ca}^{2+}\right)$ and the lipid second messenger diacylglycerol (DAG) are required for CPKCs activation. DAG, but not $\left(\mathrm{Ca}^{2+}\right)$, activates the nPKCs. The aPKCs do not require $\mathrm{Ca}^{2+}$ or DAG for activation, but are sensitive to other lipid second messengers such as 
phosphatidylserine (PS) [8]. The activity of different PKCs is context-sensitive and these kinases can be positive or negative regulators of signaling pathways. This contextual dependency of the PKC function often makes it difficult to determine the precise roles of PKCs in normal and aberrant cellular processes [8,9]. Increased activity of several PKCs has been implicated in multiple diseases, including inflammation, sepsis, and cancer [5,9].

PKC $\delta$ is a unique $\mathrm{nPKC}$ that plays a significant role in several diseases, including cancer, diabetes, ischemic heart disease, and neurodegenerative diseases [10-19]. Recent studies from our research group and others have shown that PKC $\delta$ is also a critical regulator of the inflammatory response in sepsis [8,19-26]. While a role for PKC $\delta$ in sepsis is established, less is known about how PKC $\delta$ is activated during the inflammatory response. PKC $\delta$, unlike other members of the PKC family, is unique in its regulation by tyrosine phosphorylation on multiple sites that determine activation, localization, and substrate specificity [2,27-30]. The goals of this review are to (1) review the overall structures and subfamilies of the PKCs and general activation mechanisms, (2) present an overview of the structure and unique regulation of PKC $\delta$, and (3) describe the especially unique and critical roles of PKC $\delta$ in sepsis. We will focus on the specific phosphorylation sites of PKC $\delta$ that determine its critical role in cell signaling in inflammation. Finally, we will present genetic and pharmacological tools, as well as in vivo models, that can be used to examine the role of PKC $\delta$ in inflammation and sepsis, and how emerging tools such as microfluidics can be useful in such explorations.

The different PKCs share several common structural features (Figure 1). The catalytic domain, located at the C-terminus, contains the ATP binding site, as well as the substrate binding sites [2,5,31]. A hinge region connects the catalytic domain to the regulatory domain, which is a domain that regulates the activation state of the kinase through a pseudosubstrate region. The pseudosubstrate region is a substrate-mimicking short amino acid sequence that binds the substrate-binding cavity in the catalytic domain, rendering the enzyme inactive (Figure 2). PKCs contain several conserved membrane-targeting modules that are located in the regulatory domain $(\mathrm{C} 1$ and $\mathrm{C} 2)$ and the catalytic domain (C3 and C4) [2].
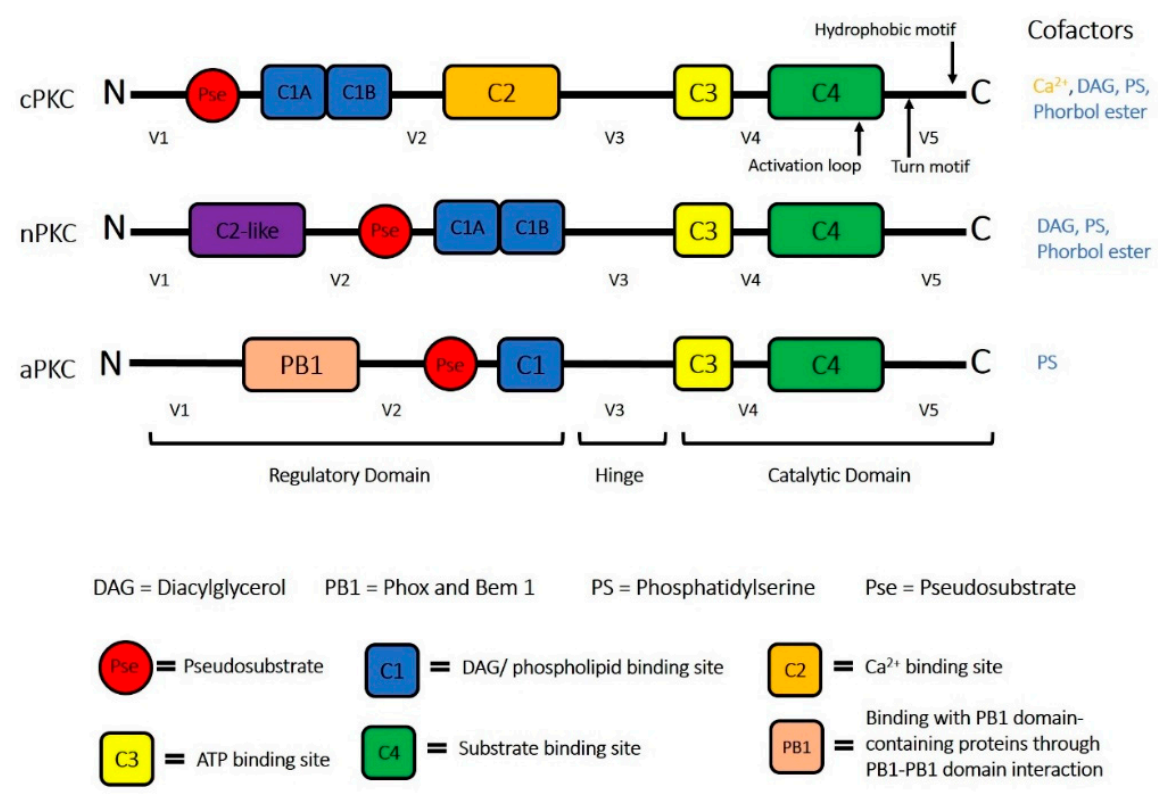

Figure 1. Structure of the three main classes of Protein Kinase C (PKC)s along with their respective activators. The hinge domain separates the regulatory domain and the catalytic domain. The regulatory domain contains: the pseudosubstrate (binds to $C 4$ when not activated) for keeping the enzyme inactive; the $\mathrm{C} 1$ domain (including $\mathrm{C} 1 \mathrm{~A}$ and $\mathrm{C} 1 \mathrm{~B}$ ) for DAG/PS/phorbol ester binding for $\mathrm{CPKC}$ and nPKCs; the $\mathrm{C} 2$ domain for $\mathrm{Ca}^{2+}$ binding; the $\mathrm{C} 2$-like domain for $\mathrm{nPKC}$ spatial distribution; and the $\mathrm{C} 1$ domain (in aPKCs) for PS binding. The catalytic domain contains the C3 domain for ATP binding and C4 domain for substrate/pseudosubstrate binding. 


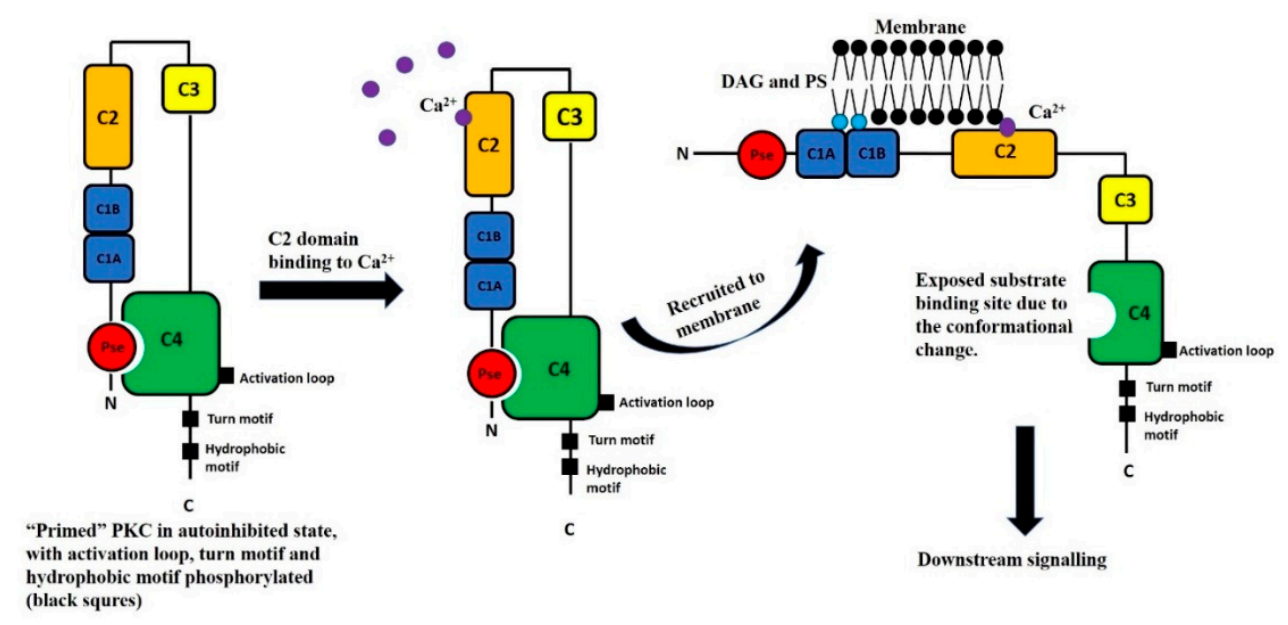

Figure 2. Schematic drawing of the activation steps of cPKCs. Following the three distinct phosphorylations at the activation loop, the turn motif, and the hydrophobic motif (for example, in human PKC $\beta$-II, corresponding to threonine 500, serine 641, and threonine 6601, respectively), PKCs are released into the cytosol, but with the pseudosubstrate occupying the substrate-binding site. Binding to $\mathrm{Ca}^{2+}$, PS, and DAG results in membrane translocation and subsequent conformational change, which releases the pseudosubstrate from the substrate-binding site.

The $\mathrm{C} 1$ region in the regulatory domain also contains the pseudosubstrate region that controls PKC activity. The $\mathrm{C} 1$ domain is also the binding site for DAG and PS, critical cofactors in CPKC and nPKC activation [5,32-34], as well as the non-hydrolysable, non-physiological analogues, phorbol esters. DAG is the product of the hydrolysis of the phospholipid phosphatidylinositol 4,5-biphosphate $\left(\mathrm{PIP}_{2}\right)$ by phospholipase C (PLC), which yields inositol triphosphate $\left(\mathrm{IP}_{3}\right)$ and DAG $[8,27,35] . \mathrm{IP}_{3}$ in turn activates signaling pathways that elevate intracellular $\mathrm{Ca}^{2+}$ levels and thereby activate cPKCs [27]. For CPKCs and nPKCs, the DAG-mediated activation is initiated by the docking of DAG/PS to the two cysteine-rich regions (C1A and $\mathrm{C} 1 \mathrm{~B})$ in the $\mathrm{C} 1$ domain. This docking event weakens the interaction of an inhibitory pseudo-substrate domain with the C-terminus catalytic core and recruits CPKCs and nPKCs to the membrane compartment [36]. cPKCs are also regulated by changes in cytosolic $\mathrm{Ca}^{2+}$ concentrations. The $\mathrm{C} 2$ domain is a critical $\mathrm{Ca}^{2+}$-sensing membrane-targeting module in cPKCs [5]. The $\mathrm{C} 2$ domain in $\mathrm{CPKCs}$ binds two or three calcium ions [37-39] and facilitates the docking of $\mathrm{CPKCs}$ to the plasma membrane. In nPKCs, the C2-like domain lacks one or more of the conserved aspartate residues required for $\mathrm{Ca}^{2+}$ binding, and these isoforms are activated by DAG/PS in the absence of $\mathrm{Ca}^{2+}[5,29]$. The function of the $\mathrm{C} 2$-like domain in $\mathrm{nPKC}$ s remains unclear. It is speculated that the C2-like domain is involved in the control of the nPKC spatial distribution via protein-protein interactions [31]. aPKCs, on the other hand, lack the $\mathrm{C} 2$ domain and have an incomplete $\mathrm{C} 1$ domain. Thus, aPKCs are $\mathrm{Ca}^{2+}$-insensitive, and do not respond to DAG. aPKCs are activated through the Phox and Bem 1 (PB1) domain, which is a protein interaction module that mediates aPKCs interactions with other PB1domain-containing scaffolding proteins and phospholipid co-factors such as PS [4,5,8,40,41]. The $\mathrm{C} 3$ and $\mathrm{C} 4$ domains form the ATP- and substrate-binding components, respectively, of the kinase core [34].

PKCs also contain five variable regions, which are poorly conserved across the different PKCs [5]. For example, in PKC $\delta$, the V1 region contains the translocation inhibitor site; V2 contains the translocation activation site; V3 (at the hinge region) contains serine phosphorylation sites at 299, 302, 304, and tyrosine 311 and 322 phosphorylation sites; V4 contains the ATP binding sequence; and V5 contains the turn and hydrophobic motifs, as well as serine 643 and 662 phosphorylation sites (Figure 3) [5].

In order for these allosteric interactions to occur, however, PKCs must first be properly folded and in the correct conformation permissive for catalytic action (Figure 2). This is contingent upon phosphorylation of the catalytic region, at the activation loop, the turn motif, and the hydrophobic 
motif [42]. First, PKCs are phosphorylated on the activation loop by phosphoinositide-dependent kinase, PDK-1, which functions as a switch to elicit the other two phosphorylations. Next, the turn motif and hydrophobic motif are autophosphorylated. After the three "priming" phosphorylation steps, the kinase is mature and released to the cytosol and is thus ready to respond to second messengers. It is worth noting that the activation loop phosphorylation is not required for the entire regulation process. Once the first step of phosphorylation is completed, the activation loop may be dephosphorylated [42].

Though the binding of DAG does not lead to a significant conformational change, it dramatically alters the surface properties of the kinase to create a hydrophobic surface for tight membrane binding. After binding to the membrane, the interaction of the $\mathrm{C} 1$ domain and the membrane leads to a conformational change that releases the pseudosubstrate from the substrate-binding site (Figure 2). This process readies the kinase to phosphorylate other proteins for downstream signaling. In the resting state, the pseudosubstrate of the regulatory domain occupies the substrate-binding site in the catalytic domain and maintains the enzyme in an inactive conformation.

\section{PKC $\delta$ and Its Unique Role in Health and Disease}

We have identified PKC $\delta$ as an import regulator of the inflammatory response in sepsis $[8,19,22,43-47]$. Multiple cell types express PKC $\delta$ and proinflammatory mediators involved in the septic response activate this kinase $[44,48]$. Importantly, PKC $\delta$ regulates neutrophil and endothelial proinflammatory signaling $[22,46,47]$. In neutrophils, PKC $\delta$ regulates inflammatory signaling, activation of the transcription factor NF- $\mathrm{kB}$ and proinflammatory gene expression, secretion of cytokines/chemokines, and reactive oxygen species (ROS) production [22,46]. In endothelial cells, PKC $\delta$ is involved in NF- $\mathrm{BB}$ activation, adhesion molecule expression, the release of inflammatory mediators important in neutrophil transmigration, and regulation of endothelial cell permeability [23,47]. Thus, PKC $\delta$ is an important signaling element in the regulation of neutrophil-endothelial crosstalk, neutrophil adherence/rolling/migration, and vascular endothelial damage $[8,19,21-23,46,47]$.

\subsection{PKC $\delta$ Activation}

PKC $\delta$, unlike other members of the PKC family, is unique in its regulation by tyrosine phosphorylation, activation mechanisms, and multiple subcellular targets [2,27].

\subsubsection{PKC $\delta$ Phosphorylation}

PKC $\delta$ activity is regulated by phosphorylation patterns, subcellular translocation, and cleavage in a context-dependent manner [2,29]. The three main conserved threonine and serine phosphorylation sites for PKC $\delta$ are Threonine-505 (Thr-505, activation loop), Serine-643 (Ser-643, turn motif), and Serine-662 (Ser-662, hydrophobic motif) [27]. However, PKC $\delta$ retains little phosphorylation in the activation loop (Thr-505) in many cell types [27]. Unlike other PKCs, mutations of Thr-505 to Alanine in PKC $\delta$ do not affect catalytic activity, but may be important for enzyme stability $[27,49]$. In general, phosphorylation of Ser-643 and Ser-662 is necessary for PKC $\delta$ catalytic activation and Thr-505 phosphorylation can enhance the catalytic activity of PKC $\delta$ [27,50-52].

Unlike serine and threonine phosphorylation, tyrosine phosphorylation is not conserved among the different PKCs and PKC $\delta$ activation is uniquely regulated by tyrosine phosphorylation patterns (Figure 3) $[27,29,53]$. Human PKC $\delta$ contains 20 tyrosine residues (19 for mice and 21 for rat) [29], and includes phosphorylation sites in the regulatory domain (Tyr-52, Tyr-64, Tyr-155, and Tyr-187), the hinge region (Tyr-311 and Tyr-332), and the catalytic domain (Tyr-505, Tyr-512, and Tyr-523) [27]. Tyrosine phosphorylation of the catalytic domain increases PKC $\delta$ activity, while tyrosine phosphorylation in the regulatory domain influences cellular actions rather than catalytic competence [2,12]. 


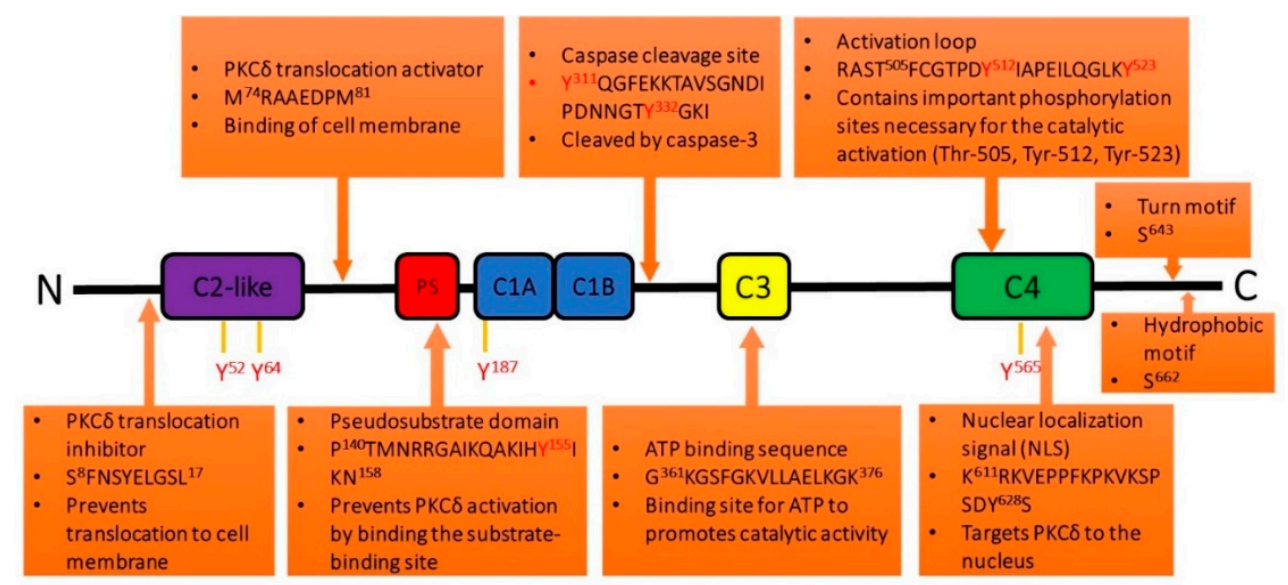

Figure 3. Important amino acid sequences (activators, inhibitors, regulatory signals) and tyrosine phosphorylation sites on PKC $\delta$. Adapted from Malavez et al., 2009 [27].

Two important tyrosine phosphorylation sites are PKC $\delta$ Tyr-155 and PKC $\delta$ Tyr-311, which are critical phosphorylation sites associated with PKC $\delta$-mediated proinflammatory signaling and the initiation of cytotoxic/apoptotic pathways [54-56]. Phosphorylation of PKC $\delta$ at Tyr-155 and Tyr-311 is required for nuclear translocation and enzyme cleavage [24,54,55]. Tyr-155 is located between the regulatory domain pseudo-substrate motif and the $\mathrm{C} 1 \mathrm{~A}$ domain and regulates apoptosis and gene expression $[29,30,57]$. PKC $\delta$ phosphorylation at Tyr-311, located in the hinge region, causes a conformational change that reveals the caspase cleavage site [29]. Our recent studies demonstrate that PKC $\delta$ Tyr-155 and PKC $\delta$ Tyr-311 are phosphorylated during sepsis and play key roles in sepsis-induced lung injury, the regulation of microvascular endothelium barrier function, and neutrophil-endothelial cell interactions (See Sections 2.2.3 and 2.2.4) [21,24]. Tyr-155 phosphorylation is also significant in cell apoptosis; mutations of this site increase cell proliferation in response to PMA [27,30]. Tyr-187 is a major phosphorylation site in response to PMA, PDGF, and etoposide, but does not appear to affect PKC $\delta$ kinase activity [12,58]. Tyr-187 and Tyr-64 are important phosphorylation sites for etoposide-induced apoptosis [58]. Tyr-52 is unique to PKC $\delta$ and located at the C2 domain [29,59]. Lyn, a member of the Src family kinases, phosphorylates PKC $\delta$ on Tyr-52, and this phosphorylated tyrosine residue then serves as a docking site for the SH2 (Src homology 2) domain of Lyn and reciprocal phosphorylation [60-62]. Tyr-52 is also phosphorylated in response to IgE in leukemia cells, and IgE-stimulated PKC $\delta$ phosphorylation reduces its activity to certain substrates, suggesting that PKC $\delta$ tyrosine phosphorylation may be important in substrate recognition [58]. Tyr-311, Tyr-332, and Tyr-512 are important phosphorylation sites for kinase activation and subcellular localization $[12,27,58]$. In addition, PKC $\delta$ Tyr-332 phosphorylation creates a docking site for Shc [12].

In addition to identification of the different functions and mechanisms of the individual tyrosine phosphorylation sites of $\mathrm{PKC} \delta$, the identification of $\mathrm{PKC} \delta$-specific substrates is also important to understand how this kinase regulates cellular function. Table 1 summarizes proteins identified as PKC $\delta$ substrates. For example, PKC $\delta$ preserves homeostasis by phosphorylating plasma membrane calcium ATPase (PMCA) that helps regulate calcium levels in the skin $[27,63,64]$. PKC $\delta$ phosphorylates caspase- 3 in human monocytes, which promotes the apoptotic activity of caspase- 3 both in vitro and in vivo [65]. PKC $\delta$ also phosphorylates the p52Shc protein at Ser-29 (when under oxidative stress), p66Shc at Ser-138 (ERK activation), and Heat Shock Protein 25 (HSP25) through binding at the V5 region, leading to the inhibition of apoptosis [29,66-68]. Additional substrates of PKC $\delta$ have been discovered with the aid of PKC $\delta$ inhibitors and activators, such as cytoskeleton proteins [28], the myristoylated alanine-rich C-kinase substrate (MARCKS) [28,69], troponin [28,70], the nuclear protein DNA-dependent protein kinase [28,71], and pyruvate dehydrogenase (a mitochondrial enzyme) [28,72]. Thus, PKC $\delta$ has a myriad of phosphorylation targets, and further studies are required to determine 
the targets of PKC $\delta$ phosphorylation in specific cells and in various disease conditions, particularly in sepsis.

\subsubsection{PKC $\delta$ Translocation and Subcellular Localization}

PKC $\delta$ has been classically known to move from the cytosol to the plasma membrane upon activation into a mature, catalytically competent form. However, recent investigations have revealed that $\mathrm{PKC} \delta$ can move to several subcellular compartments, including mitochondria, endoplasmic reticulum (ER), Golgi apparatus, nuclei, and caveolae [48,73-76]. This translocation of PKC $\delta$ is mediated by tyrosine phosphorylation [29]. In cardiomyocytes, PKC $\delta$ moves from the nucleus to focal contacts and cytoskeleton and around the nucleus [48]. PMA can enhance the movement of PKC $\delta$ to caveolae, leading to increased ERK activity [73]. PKC $\delta$ in its tyrosine phosphorylated form can also accumulate in the soluble portion of hydrogen peroxide-treated cardiomyocytes and, in itself, can act as a lipid-independent kinase [29]. PKC $\delta$ can transiently translocate to the ER following ER stress and binds to $\mathrm{Abl}$ (a tyrosine kinase) [74]. After briefly translocating to the ER, PKC $\delta$ then accumulates in the mitochondria, inducing apoptosis [74]. In human leukemia cells, ceramide release is caused by TNF- $\alpha$-initiated apoptosis and the translocation of PKC $\delta$ from the plasma membrane to Golgi apparatus [75]. In glioma cells, PKC $\delta$ was found to induce apoptosis when targeted to the cytoplasm, nucleus, and mitochondria, whereas the ER translocation protected the cells from TNF-ligand-induced cell death [76]. Overall, there is no uniform pattern of PKC $\delta$ tyrosine phosphorylation and it is becoming more evident that the precise configuration of tyrosine phosphorylation depends on the stimulus that dictates the functional properties of the enzyme and its subcellular location. For example, in platelets, thrombin-induced Tyr-311 phosphorylation on PKC $\delta$ occurs subsequent to Thr-505 phosphorylation, while ADP-induced Tyr-311 phosphorylation does not appear to require the threonine phosphorylation [77]. In a rodent model of sepsis, pulmonary PKC $\delta$ is phosphorylated on both Tyr-155 and Tyr-311, resulting in PKC $\delta$ nuclear translocation and PKC $\delta$ cleavage [24]. Thus, PKC $\delta$ activation is stimulus-dependent and cell type-specific.

Table 1. PKC $\delta$ substrates and functions. Adapted from Steinberg 2004 [29].

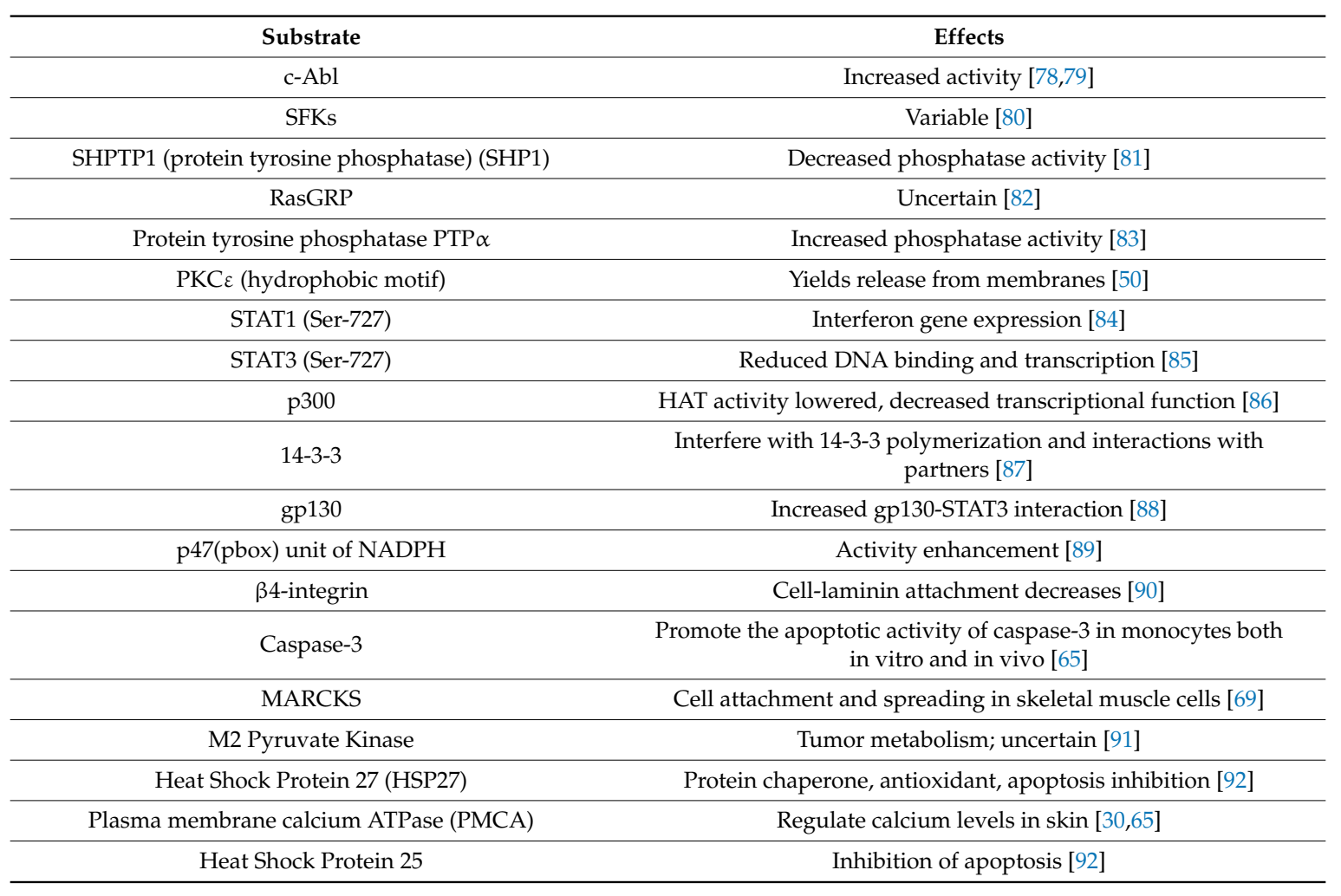


Table 1. Cont.

\begin{tabular}{cc}
\hline Substrate & Effects \\
\hline $\begin{array}{c}\text { p52Shc protein } \\
\text { p66Shc protein }\end{array}$ & $\begin{array}{c}\text { Positively regulates H2O2-induced ERK activation [67] } \\
\text { Negatively regulates H2O2-induced ERK activation [67] }\end{array}$ \\
\hline Troponin & Decreased Calcium sensitivity of actomyosin [70] \\
\hline Pyruvate Dehydrogenase Kinase & $\begin{array}{c}\text { Inhibition of PDH resulting in necrosis and blocking ATP } \\
\text { regeneration [71] }\end{array}$ \\
\hline DNA-dependent protein kinase & Inhibition of p53 phosphorylation [93] \\
\hline Bcl-2-associated death promoter (BAD) & Promotes apoptosis post-reperfusion after cardiac ischemia [94] \\
\hline Dynamin-related protein 1 (Drp1) & Induction of mitochondrial fission and dysfunction following \\
cardiac ischemia [17]
\end{tabular}

\subsection{PKC $\delta$ in Inflammatory Diseases}

We identified PKC $\delta$ as a critical regulator of the inflammatory response in sepsis and an important signal transducer of multiple signaling pathways [8,19-23,25,43-47]. PKC $\delta$ is activated by inflammatory mediators involved in sepsis, including pathogen associated molecular patterns (PAMPs) such as LPS and the bacterial peptide fMLP, as well as the proinflammatory cytokines TNF and IL-1 $[44,48,99]$. Moreover, PKC $\delta$ is activated in multiple cell types and organs in animal models of sepsis $[19,47]$. Key to sepsis-induced tissue damage is the excessive migration of activated neutrophils across the vascular endothelium [100-103]. Studies with $\mathrm{PKC} \delta^{-/-}$mice and PKC $\delta$ inhibitors indicate a role for PKC $\delta$ in regulating neutrophil trafficking to the lung in response to inflammation triggered by bacterial sepsis, asbestos, stroke/reperfusion injury, LPS, or pancreatitis $[19,20,24,47,104-107]$.

\subsubsection{Role of PKC $\delta$ in Sepsis-Animal Studies}

During sepsis, systemic inflammation leads to increased adhesion molecule expression on neutrophils and endothelial cells, resulting in increased neutrophil-endothelial cell interaction, vascular endothelial damage, and organ dysfunction [108-110]. While neutrophils are critical to host defense, neutrophil dysregulation has a critical role in the early course of organ damage through the release of proteases, neutrophil extracellular traps (NETs), and oxygen radicals. Increased neutrophil recruitment in sepsis is associated with tissue damage, multiple organ dysfunction syndrome (MODS), and increased mortality [100-102,111].

Using a clinically relevant rodent model of polymicrobial sepsis induced by cecal ligation and puncture (CLP), we found significant lung injury within $24 \mathrm{hrs}$ post CLP surgery, including increased neutrophil accumulation in lung tissue, pulmonary permeability, tissue edema, altered lung mechanics, and disrupted lung architecture $[19,20,24,47]$. In this sepsis model, we found PKC $\delta$ activation and phosphorylation on multiple sites, including Ser-643/676, Thr-505, Tyr-155, and Tyr-311 [19,24,25].

To examine the regulatory role of PKC $\delta$ in sepsis, we employed a selective peptide inhibitor developed by Mochly-Rosen's group [13]. This inhibitory peptide is derived from the first unique region (V1) of PKC $\delta$ (SFNSYELGSL; amino acid residues 8 to 17, see Figure 3), targets docking domains, and prevents translocation and substrate interaction [13]. This inhibitor targets the regulatory domain of PKC $\delta$, but not the ATP binding site, so it is more specific than previously described PKC $\delta$ inhibitors such as rottlerin. Rottlerin has been shown to be a mitochondria uncoupler and, in recent years, has been shown to modulate biological and biochemical events in a PKC $\delta$-independent manner [112,113]. This PKC $\delta$ peptide inhibitor is coupled to a membrane permeant TAT peptide (YGRKKRRQRRR) that 
allows safe and effective intracellular delivery into target cells in vitro and in vivo [13,19,22,46,114,115]. Administration of the PKC $\delta$ peptide inhibitor in our animal model of sepsis decreased pulmonary PKC $\delta$ phosphorylation, attenuated lung injury, and improved gas exchange, indicating that PKC $\delta$ inhibition is lung protective in sepsis $[19,20,24,47]$.

Further studies demonstrated that PKC $\delta$ inhibition reduced neutrophil influx into multiple organs, including the lung, kidney, and brain $[20,24,25,47]$. The vascular endothelium is involved in the pathogenesis of sepsis and is an active participant in the dynamic process of recruitment and activation of neutrophils through the production of chemokines/cytokines and expression of adhesion molecules [100,116-119]. ICAM-1 and VCAM-1 are crucial vascular endothelial cell adhesion molecules involved in neutrophil recruitment and are up-regulated by proinflammatory cytokines released during sepsis [120]; their expression was, however, attenuated by the administration of the PKC $\delta$ peptide inhibitor [47]. These studies suggest a link among PKC $\delta$ activity, the upregulation of adhesion molecules, and increased neutrophil migration in the injured lung. PKC $\delta$ was also activated in the brain in this sepsis model, resulting in increased $\mathrm{PKC} \delta$ Ser-643 phosphorylation and membrane translocation [25]. PKC $\delta$ activation was associated with increased blood brain barrier (BBB) permeability that was attenuated by administration of the PKC $\delta$ peptide inhibitor [25].

\subsubsection{Role of PKC $\delta$ in Neutrophil-Endothelial Cell Interactions-In Vitro Studies Using Microfluidics-Based Biomimetic Assays}

Microfluidic systems provide a unique opportunity to explore in vitro the role of PKC $\delta$ in regulating neutrophil-endothelial cell interaction under physiologically realistic conditions $[21,23,25,26]$. Our group developed a novel microfluidic system (Figure 4) that resolves and facilitates the real-time assessment of individual steps, including the rolling, firm arrest, spreading, and migration of neutrophils into the extra-vascular tissue space in a single system. A Geographic Information System (GIS) approach [121] was used to digitize microvascular networks for the subsequent generation of synthetic microvascular networks using soft-lithography processes to develop a bioinspired microfluidic assay (bMFA). This bMFA was based on microvascular network morphologies obtained from in vivo animal data [122-126]. This microfluidic assay consists of vascular channels in communication with a tissue compartment filled with chemoattractants via a porous barrier. Neutrophils circulate in the vascular channels on a monolayer of activated endothelial cells under physiologic shear conditions.

In the bMFA, TNF- $\alpha$ activated human endothelial cells and upregulated the expression of the adhesion molecules and neutrophil adhesion to them [23]. Neutrophil adhesion was shear-rate dependent, with increased adhesion in vessels with lower shear rates and near bifurcations [23], and endothelial cells treated with the PKC $\delta$ inhibitor showed significantly decreased neutrophil adhesion and migration, consistent with our in vivo observations [21,23]. Mechanistic studies demonstrated that PKC $\delta$ regulates expression of the adhesion molecules E-selectin and ICAM-1. PKC $\delta$ is also an important regulator of endothelial cell permeability, and PKC $\delta$ inhibition attenuated TNF $\alpha$-mediated endothelial cell permeability and decreased transendothelial electrical resistance (TEER) [25]. Similar changes in human brain microvascular endothelial cell permeability were obtained by employing a novel blood-brain-barrier (BBB) on-a-chip $\left(\mathrm{B}^{3} \mathrm{C}\right)$ microfluidic system [25] (Figure 4). Thus, PKC $\delta$ plays a key role in the regulation of proinflammatory signaling controlling the activation and recruitment of neutrophils and in regulating endothelial permeability, TEER, and tight junction protein expression $[8,19-21,23-25,47]$.

PKC $\delta$ is also an important regulator of neutrophil-endothelial cell interactions in radiation-induced inflammation and vascular injury. Studies from our group and others have shown that the exposure of tissue to ionizing radiation (IR) causes an increase in leukocyte infiltration across endothelium and loss of barrier function [127-130]. Key to radiation-induced tissue damage is the excessive migration of activated neutrophils across the vascular endothelium [131,132]. In studies with human endothelial cells, we found that exposure to X-ray radiation ( $0.5-5 \mathrm{~Gy})$ activated PKC $\delta$ 
through phosphorylation (Ser-643) and translocation to membrane fraction [26]. Using our bMFA, we showed that PKC $\delta$ regulates radiation-induced neutrophil-endothelial cell interaction and endothelial cell function, and that PKC $\delta$ inhibition dramatically attenuated IR-induced endothelium permeability and significantly decreased neutrophil migration across IR treated endothelial cells [26]. Moreover, neutrophil adhesion to irradiated endothelial cells was significantly decreased after PKC $\delta$ inhibition in a flow-dependent manner. PKC $\delta$ inhibition downregulated the IR-induced overexpression of P-selectin, ICAM-1, and VCAM-1, but not of E-selectin. Thus, PKC $\delta$ is an important regulator of neutrophil-endothelial cell interaction post-IR exposure.

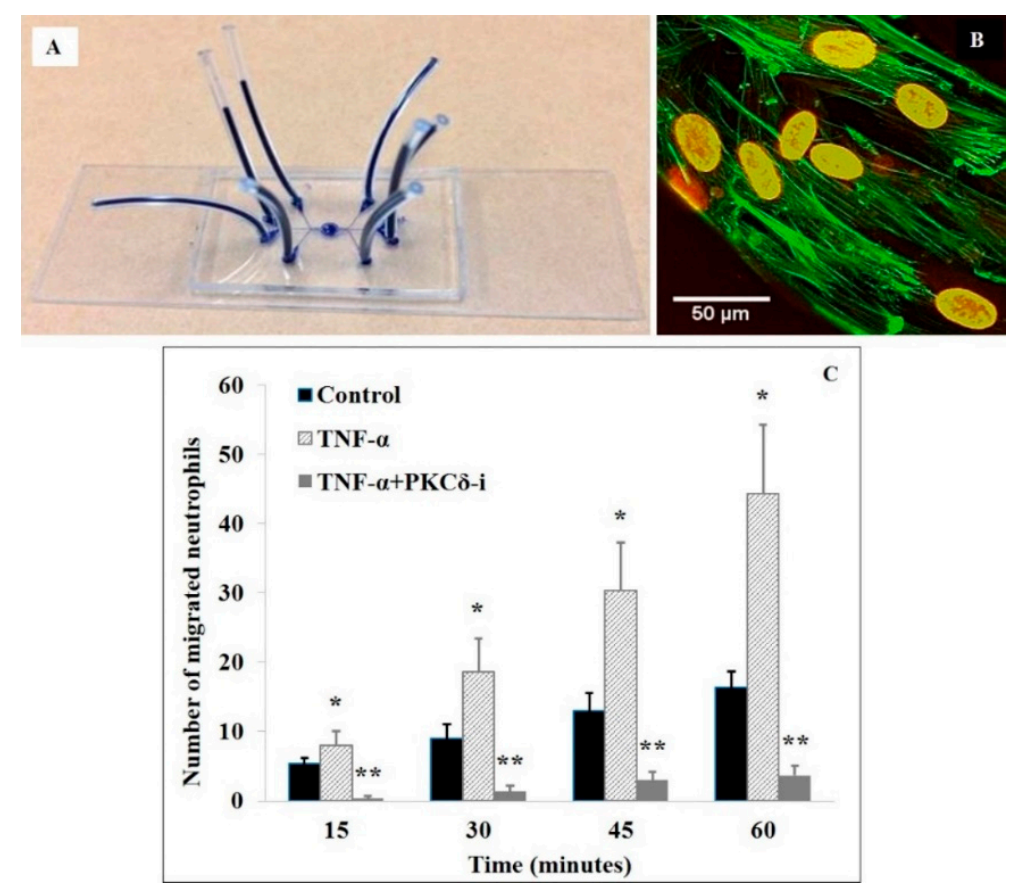

Figure 4. Microfluidic-based in vitro assay for studying the role of PKC $\delta$ in regulating neutrophil-endothelial cell interaction. (A) The assay is manufactured by soft lithography on polydimethylsiloxane (PDMS) and assembled on a microscope glass slide with plastic tubes (dark blue) allowing access to individual vascular channels and the tissue compartment. (B) 3D reconstruction of confocal images of human brain microvascular endothelial cells (HBMVEC) stained for F-actin with fluorescently labelled phalloidin (green) and for cell nuclei with Draq 5 (red) after $72 \mathrm{hrs}$ of flow culture (0.1 $\mathrm{LL} / \mathrm{min})$. (C) PKC $\delta$ inhibition with a PKC $\delta$-TAT peptide inhibitor (PKC $\delta$-i) reduces neutrophil migration across activated HBMVEC. Data are presented as mean $\pm \operatorname{SEM}(n=3) .{ }^{* *} p<0.01,{ }^{*} p<0.05$ compared to the other two groups by ANOVA with Tukey-Kramer post-hoc. Reprinted with permission from Tang et al., 2018 [25].

\subsubsection{PKC $\delta$ Phosphorylation in Sepsis and Inflammation—In Vivo Studies}

Our in vivo studies demonstrated that sepsis triggered significant tyrosine phosphorylation of PKC $\delta$ [24]. Sepsis-induced lung injury was characterized by the phosphorylation of PKC $\delta$ at Tyr-311 throughout the distal lung, which is consistent with the finding that Tyr-311 is a critical phosphorylation site in the context of vascular inflammation $[24,133]$. Of particular interest, pulmonary endothelial cells, in contrast to pulmonary macrophages and epithelial cells, were the primary cell type exhibiting Tyr-155 phosphorylation in response to sepsis (Figure 5) [24]. This is a key observation, as in sepsis, pulmonary endothelium contains the first cells in the lung to encounter systemic proinflammatory mediators, making them the frontline inflammatory responders in systemic inflammation.

To interrogate the role of Tyr-155 phosphorylation in sepsis-induced lung injury and neutrophil recruitment to the lungs, PKC $\delta$ knock-in (KI) mice were produced where PKC $\delta$ Tyr-155 was mutated to phenylalanine (PKC $\delta$ Y155F KI mice) [21]. Compared to wild-type (WT) septic mice, there was a 
significant decrease in neutrophil recruitment to the lungs in PKC 8 Y155F KI septic mice, indicating an important role for Tyr-155 phosphorylation in regulating proinflammatory activity during sepsis [21].

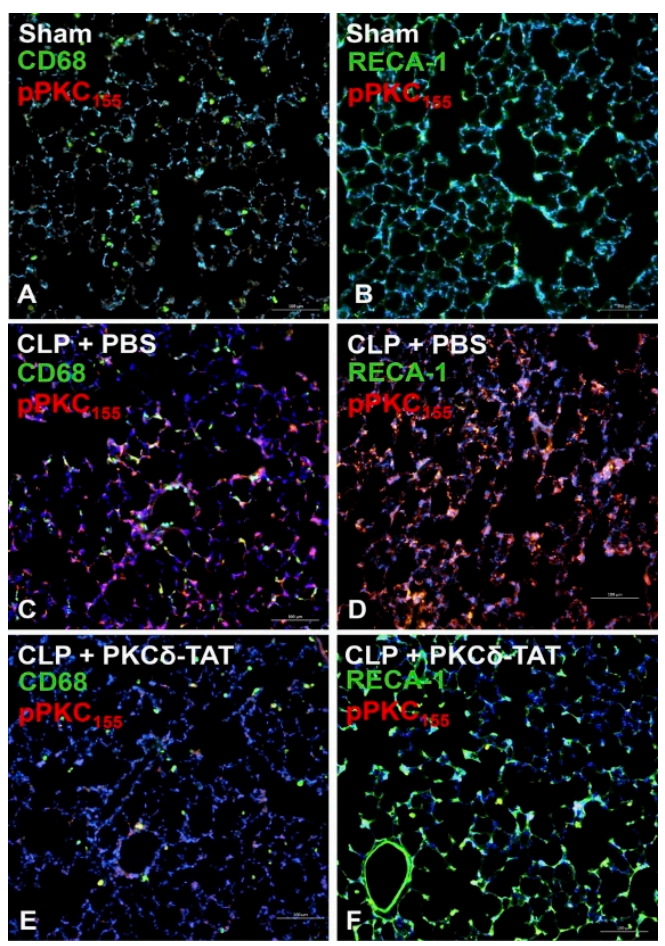

Figure 5. Immunohistochemical analysis of PKC $\delta$ phosphorylation at tyrosine 155 (pPKC $\delta_{155}$; red) in lung tissue sections at $24 \mathrm{~h}$ post-surgery of sham-operated animals (Sham) (A,B) and CLP-operated animals that received $200 \mu \mathrm{g} / \mathrm{kg}$ PKC $\delta$-TAT $(\mathrm{CLP}+\mathrm{PKC} \delta$-TAT) $(\mathbf{E}, \mathbf{F})$ or a similar volume of PBS vehicle only (CLP + PBS) (C,D) immediately following surgery. (A,C,E) Tissue sections were also stained for CD68 (green), a marker for the cells of the macrophage lineage. Yellow/orange indicates co-localization of $\mathrm{pPKC} \delta_{155}$ and CD68. (B,D,F) Tissue sections were also stained for rat endothelial cell antigen-1 (RECA-1; green), a marker for rat endothelial cells. Yellow/orange indicates co-localization of pPKC $\delta_{155}$ and RECA-1. All scale bars $=100$ microns. Reprinted with permission from Mondrinos et al., 2015 [24].

\subsubsection{PKC $\delta$ Phosphorylation in Sepsis and Inflammation-In Vitro Studies}

To investigate the role of PKC $\delta$ Tyr-155 phosphorylation in neutrophil superoxide anion $\left(\mathrm{O}_{2}{ }^{-}\right)$

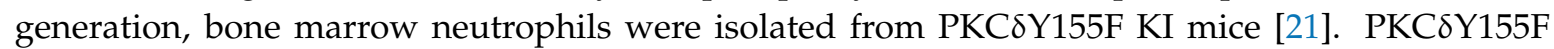
bone marrow neutrophil $\mathrm{O}_{2}{ }^{-}$production in response to fMLP or TNF $\alpha$ activation was significantly decreased compared to WT mice. Decreased $\mathrm{O}_{2}{ }^{-}$production was stimulus-dependent as PMA-mediated $\mathrm{O}_{2}{ }^{-}$generation was not affected. Formation of neutrophil extracellular traps (NETs) from PKC 8 Y155F KI mice was also attenuated in response to IL-1 or TNF as compared to WT mice. Hence, PKC $\delta$ is an important regulator of $\mathrm{O}_{2}^{-}$and NETs release, and PKC $\delta$ Tyr-155 is a key phosphorylation site regulating proinflammatory signaling controlling neutrophil activation [21].

To investigate further the role of PKC $\delta$ Tyr-155 phosphorylation in neutrophil-endothelial interaction in inflammation, we employed the bMFA to examine endothelial cell permeability and neutrophil migration [21]. Our studies demonstrate that the Tyr-155 phosphorylation site is a critical regulator of endothelium barrier function, neutrophil adhesion, and neutrophil transmigration. Consistent with our previous findings [21,23], PKC $\delta$ was found to play a more significant role in regulating the migration of neutrophils across endothelial cells as opposed to their adhesion to endothelial cells. Overall, these findings indicate that regulating PKC $\delta$ activity may provide novel therapeutic strategies for treating inflammation. 


\section{Concluding Remarks}

The Protein Kinase $C$ superfamily consists of multiple isoforms with separate and overlapping cellular and physiological functions that contribute to health and disease. Among them, PKC $\delta$ has a unique tyrosine phosphorylation pattern that diminishes or enhances biological processes such as neutrophil and platelet adhesion, migration, and adhesion molecule expression. Furthermore, the inhibition of PKC $\delta$ may offer a therapeutic pathway for reducing neutrophil-mediated organ damage in inflammatory diseases. Emerging in vitro methods (e.g., microfluidic platforms) provide unique perspectives for delineating biological mechanisms in a physiologically relevant environment prior to observation and study in animal models or clinical settings, reducing drug development costs and providing more precise and personalized diagnostic/treatment methods.

Author Contributions: Q.Y., J.C.L., and Y.T. prepared the manuscript. M.F.K. and L.E.K. developed the ideas and edited the manuscript.

Funding: This work was supported by the American Heart Association (grant No. 16GRNT29980001 to M.F.K.) and National Institutes of Health (grant No. GM114359 to M.F.K. and L.E.K.).

Conflicts of Interest: The authors declare no conflict of interest.

\section{References}

1. Inoue, M.; Kishimoto, A.; Takai, Y.; Nishizuka, Y. Studies on a cyclic nucleotide-independent protein kinase and its proenzyme in mammalian tissues. II. Proenzyme and its activation by calcium-dependent protease from rat brain. J. Biol. Chem. 1977, 252, 7610-7616.

2. Steinberg, S.F. Structural Basis of Protein Kinase C Isoform Function. Physiol. Rev. 2008, 88, 1341-1378. [CrossRef]

3. Dempsey, E.C.; Newton, A.C.; Mochly-Rosen, D.; Fields, A.P.; Reyland, M.E.; Insel, P.A.; Messing, R.O. Protein kinase $\mathrm{C}$ isozymes and the regulation of diverse cell responses. Am. J. Physiol. Lung Cell Mol. Physiol. 2000, 279, L429-L438. [CrossRef]

4. Sabri, A.; Steinberg, S.F. Protein kinase $C$ isoform-selective signals that lead to cardiac hypertrophy and the progression of heart failure. In Biochemistry of Hypertrophy and Heart Failure; Springer: New York, NY, USA, 2003; pp. 97-101.

5. Mellor, H.; Parker, P.J. The extended protein kinase C superfamily. Biochem. J. 1998, 332, 281-292. [CrossRef] [PubMed]

6. Hayashi, A.; Seki, N.; Hattori, A.; Kozuma, S.; Saito, T. PKCv, a new member of the protein kinase C family, composes a fourth subfamily with PKC $\mu 1$. Biochim. Biophys. Acta (BBA) Mol. Cell Res. 1999, 1450, 99-106. [CrossRef]

7. Lenz, J.C.; Reusch, H.P.; Albrecht, N.; Schultz, G.; Schaefer, M. Ca ${ }^{2+}$-controlled competitive diacylglycerol binding of protein kinase C isoenzymes in living cells. J. Cell Biol. 2002, 159, 291-302. [CrossRef]

8. Mondrinos, M.J.; Kennedy, P.A.; Lyons, M.; Deutschman, C.S.; Kilpatrick, L.E. Protein Kinase C and Acute Respiratory Distress Syndrome. Shock 2013, 39, 467-479. [CrossRef]

9. Mochly-Rosen, D.; Das, K.; Grimes, K.V. Protein kinase C, an elusive therapeutic target? Nat. Rev. Drug Discov. 2012, 11, 937. [CrossRef] [PubMed]

10. Ono, Y.; Fujii, T.; Ogita, K.; Kikkawa, U.; Igarashi, K.; Nishizuka, Y. The structure, expression, and properties of additional members of the protein kinase C family. J. Biol. Chem. 1988, 263, 6927-6932.

11. Kim, J.; Koyanagi, T.; Mochly-Rosen, D. PKC $\delta$ activation mediates angiogenesis via NADPH oxidase activity in PC-3 prostate cancer cells. Prostate 2011, 71, 946-954. [CrossRef] [PubMed]

12. Bright, R.; Raval, A.P.; Dembner, J.M.; Perez-Pinzon, M.A.; Steinberg, G.K.; Yenari, M.A.; Mochly-Rosen, D. Protein kinase C $\delta$ mediates cerebral reperfusion injury in vivo. J. Neurosci. 2004, 24, 6880-6888. [CrossRef] [PubMed]

13. Chen, L.; Hahn, H.; Wu, G.; Chen, C.H.; Liron, T.; Schechtman, D.; Cavallaro, G.; Banci, L.; Guo, Y.; Bolli, R.; et al. Opposing cardioprotective actions and parallel hypertrophic effects of $\delta$ PKC and epsilon PKC. Proc. Natl. Acad. Sci. USA 2001, 98, 11114-11119. [CrossRef] [PubMed] 
14. Inagaki, K.; Chen, L.; Ikeno, F.; Lee, F.H.; Imahashi, K.; Bouley, D.M.; Rezaee, M.; Yock, P.G.; Murphy, E.; Mochly-Rosen, D. Inhibition of $\delta$-protein kinase $C$ protects against reperfusion injury of the ischemic heart in vivo. Circulation 2003, 108, 2304-2307. [CrossRef]

15. Pereira, S.; Park, E.; Mori, Y.; Haber, C.A.; Han, P.; Uchida, T.; Stavar, L.; Oprescu, A.I.; Koulajian, K.; Ivovic, A. FFA-induced hepatic insulin resistance in vivo is mediated by PKC $\delta$, NADPH oxidase, and oxidative stress. Am. J. Physiol. Endocrinol. Metab. 2014, 307, E34-E46. [CrossRef] [PubMed]

16. Geraldes, P.; Hiraoka-Yamamoto, J.; Matsumoto, M.; Clermont, A.; Leitges, M.; Marette, A.; Aiello, L.P.; Kern, T.S.; King, G.L. Activation of PKC- $\delta$ and SHP-1 by hyperglycemia causes vascular cell apoptosis and diabetic retinopathy. Nat. Med. 2009, 15, 1298. [CrossRef]

17. Qi, X.; Disatnik, M.-H.; Shen, N.; Sobel, R.A.; Mochly-Rosen, D. Aberrant mitochondrial fission in neurons induced by protein kinase $\mathrm{C} \delta$ under oxidative stress conditions in vivo. Mol. Biol. Cell 2011, 22, $256-265$. [CrossRef]

18. Qi, X.; Inagaki, K.; Sobel, R.A.; Mochly-Rosen, D. Sustained pharmacological inhibition of $\delta$ PKC protects against hypertensive encephalopathy through prevention of blood-brain barrier breakdown in rats. J. Clin. Investig. 2008, 118, 173-182. [CrossRef] [PubMed]

19. Kilpatrick, L.E.; Standage, S.W.; Li, H.; Raj, N.R.; Korchak, H.M.; Wolfson, M.R.; Deutschman, C.S. Protection against sepsis-induced lung injury by selective inhibition of protein kinase C- $\delta(\delta-P K C)$. J. Leuk. Biol. 2011, 89, 3-10. [CrossRef] [PubMed]

20. Liverani, E.; Mondrinos, M.J.; Sun, S.; Kunapuli, S.P.; Kilpatrick, L.E. Role of Protein Kinase C- $\delta$ in regulating platelet activation and platelet-leukocyte interaction during sepsis. PLoS ONE 2018, 13, e0195379. [CrossRef]

21. Soroush, F.; Tang, Y.; Guglielmo, K.; Engelmann, A.; Liverani, E.; Langston, J.; Sun, S.; Kunapuli, S.; Kiani, M.F.; Kilpatrick, L.E. Protein Kinase C- $\delta(\mathrm{PKC} \delta$ ) Tyrosine Phosphorylation is a Critical Regulator of Neutrophil-Endothelial Cell Interaction in Inflammation. Shock 2018. [CrossRef]

22. Kilpatrick, L.E.; Sun, S.; Li, H.; Vary, T.C.; Korchak, H.M. Regulation of TNF-induced oxygen radical production in human neutrophils: Role of $\delta$-PKC. J. Leuk. Biol. 2010, 87, 153-164. [CrossRef] [PubMed]

23. Soroush, F.; Zhang, T.; King, D.J.; Tang, Y.; Deosarkar, S.; Prabhakarpandian, B.; Kilpatrick, L.E.; Kiani, M.F. A novel microfluidic assay reveals a key role for protein kinase $C \delta$ in regulating human neutrophil-endothelium interaction. J. Leuk. Biol. 2016, 100, 1027-1035. [CrossRef] [PubMed]

24. Mondrinos, M.J.; Knight, L.C.; Kennedy, P.A.; Wu, J.; Kauffman, M.; Baker, S.T.; Wolfson, M.R.; Kilpatrick, L.E. Biodistribution and efficacy of targeted pulmonary delivery of a protein kinase C- $\delta$ inhibitory peptide: Impact on indirect lung injury. J. Pharmacol. Exp. Ther. 2015, 355, 86-98. [CrossRef] [PubMed]

25. Tang, Y.; Soroush, F.; Sun, S.; Liverani, E.; Langston, J.C.; Yang, Q.; Kilpatrick, L.E.; Kiani, M.F. Protein kinase C- $\delta$ inhibition protects blood-brain barrier from sepsis-induced vascular damage. J. Neuroinflamm. 2018, 15, 309. [CrossRef]

26. Soroush, F.; Tang, Y.; Zaidi, J.; Sheffield, L.; Kilpatrick, L.E.; Kiani, M.F. PKC $\delta$ inhibition as a novel medical countermeasure for radiation-induced vascular damage. FASEB J. 2018, 32, 1529-1533. [CrossRef] [PubMed]

27. Malavez, Y.; Gonzalez-Mejia, M.E.; Doseff, A.I. PRKCD (Protein Kinase C, Delta). Available online: http: / / atlasgeneticsoncology.org/Genes/GC_PRKCD.html (accessed on 24 March 2009).

28. Qvit, N.; Mochly-Rosen, D. The many hats of protein kinase Cdelta: One enzyme with many functions. Biochem. Soc. Trans. 2014, 42, 1529-1533. [CrossRef] [PubMed]

29. Steinberg, S.F. Distinctive activation mechanisms and functions for protein kinase C $\delta$. Biochem. J. 2004, 384, 449-459. [CrossRef] [PubMed]

30. Kronfeld, I.; Kazimirsky, G.; Lorenzo, P.S.; Garfield, S.H.; Blumberg, P.M.; Brodie, C. Phosphorylation of Protein Kinase Cd on Distinct Tyrosine Residues Regulates Specific Cellular Functions. J. Biol. Chem. 2000, 275, 35491-35498. [CrossRef]

31. Newton, A.C. Protein kinase C: Structural and spatial regulation by phosphorylation, cofactors, and macromolecular interactions. Chem. Rev. 2001, 101, 2353-2364. [CrossRef]

32. Dempsey, E.C.; Badesch, D.B.; Dobyns, E.L.; Stenmark, K.R. Enhanced growth capacity of neonatal pulmonary artery smooth muscle cells in vitro: Dependence on cell size, time from birth, insulin-like growth factor I, and auto-activation of protein Kinase, C. J. Cell. Physiol. 1994, 160, 469-481. [CrossRef]

33. Ono, Y.; FuJII, T.; Igarashi, K.; Kuno, T.; Tanaka, C.; Kikkawa, U.; Nishizuka, Y. Phorbol ester binding to protein kinase $C$ requires a cysteine-rich zinc-finger-like sequence. Proc. Natl. Acad. Sci. USA 1989, 86, 4868-4871. [CrossRef] 
34. Hommel, U.; Zurini, M.; Luyten, M. Solution structure of a cysteine rich domain of rat protein kinase C. Nat. Struct. Mol. Biol. 1994, 1, 383. [CrossRef]

35. Diaz-Meco, M.T.; Moscat, J. The atypical PKCs in inflammation: NF-кB and beyond. Immunol. Rev. 2012, 246, 154-167. [CrossRef] [PubMed]

36. Oancea, E.; Meyer, T. Protein kinase C as a molecular machine for decoding calcium and diacylglycerol signals. Cell 1998, 95, 307-318. [CrossRef]

37. Shao, X.; Davletov, B.A.; Sutton, R.B.; Südhof, T.C.; Rizo, J. Bipartite Ca ${ }^{2+}$-Binding Motif in C2 Domains of Synaptotagmin and Protein Kinase C. Science 1996, 273, 248-251. [CrossRef] [PubMed]

38. Sutton, R.B.; Sprang, S.R. Structure of the protein kinase $C \beta$ phospholipid-binding $C 2$ domain complexed with $\mathrm{Ca}^{2+}$. Structure 1998, 6, 1395-1405. [CrossRef]

39. Verdaguer, N.; Corbalan-Garcia, S.; Ochoa, W.F.; Fita, I.; Gómez-Fernández, J.C. Ca ${ }^{2+}$ bridges the C2 membrane-binding domain of protein kinase $\mathrm{C} \alpha$ directly to phosphatidylserine. EMBO J. 1999, 18, 6329-6338. [CrossRef] [PubMed]

40. Rosse, C.; Linch, M.; Kermorgant, S.; Cameron, A.J.; Boeckeler, K.; Parker, P.J. PKC and the control of localized signal dynamics. Nat. Rev. Mol. Cell Biol. 2010, 11, 103. [CrossRef]

41. Moscat, J.; Rennert, P.; Diaz-Meco, M. PKC $\zeta$ at the crossroad of NF- $\mathrm{BB}$ and Jak1/Stat6 signaling pathways. Cell Death Differ. 2006, 13, 702. [CrossRef]

42. Keranen, L.M.; Dutil, E.M.; Newton, A.C. Protein kinase C is regulated in vivo by three functionally distinct phosphorylations. Curr. Biol. 1995, 5, 1394-1403. [CrossRef]

43. Kilpatrick, L.E.; Song, Y.H.; Rossi, M.W.; Korchak, H.M. Serine phosphorylation of p60 tumor necrosis factor receptor by PKC- $\delta$ in TNF- $\alpha$-activated neutrophils. Am. J. Physiol. Cell Physiol. 2000, 279, C2011-C2018. [CrossRef] [PubMed]

44. Kilpatrick, L.E.; Lee, J.Y.; Haines, K.M.; Campbell, D.E.; Sullivan, K.E.; Korchak, H.M. A role for PKC- $\delta$ and PI 3-kinase in TNF- $\alpha$-mediated antiapoptotic signaling in the human neutrophil. Am. J. Physiol. Cell Physiol. 2002, 283, C48-C57. [CrossRef] [PubMed]

45. Kilpatrick, L.E.; Sun, S.; Korchak, H.M. Selective regulation by $\delta$-PKC and PI 3-kinase in the assembly of the antiapoptotic TNFR-1 signaling complex in neutrophils. Am. J. Physiol. Cell Physiol. 2004, 287, C633-C642. [CrossRef]

46. Kilpatrick, L.E.; Sun, S.; Mackie, D.; Baik, F.; Li, H.; Korchak, H.M. Regulation of TNF mediated antiapoptotic signaling in human neutrophils: Role of $\delta$-PKC and ERK1/2. J. Leuk. Biol. 2006, 80, 1512-1521. [CrossRef]

47. Mondrinos, M.J.; Zhang, T.; Sun, S.; Kennedy, P.A.; King, D.J.; Wolfson, M.R.; Knight, L.C.; Scalia, R.; Kilpatrick, L.E. Pulmonary Endothelial Protein Kinase C- $\delta$ (PKCd) Regulates Neutrophil Migration in Acute Lung Inflammation. Am. J. Pathol. 2014, 184, 200-213. [CrossRef]

48. Page, K.; Li, J.; Zhou, L.; Iasvovskaia, S.; Corbit, K.C.; Soh, J.W.; Weinstein, I.B.; Brasier, A.R.; Lin, A.; Hershenson, M.B. Regulation of airway epithelial cell NF-K B-dependent gene expression by protein kinase

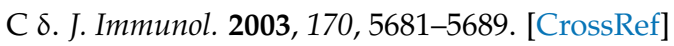

49. Stempka, L.; Girod, A.; Müller, H.-J.; Rincke, G.; Marks, F.; Gschwendt, M.; Bossemeyer, D. Phosphorylation of Protein Kinase C $\delta(\mathrm{PKC} \delta$ ) at Threonine 505 is not a prerequisite for enzymatic activity expression of rat pkc $\delta$ and an alanine 505 mutant in bacteria in a functional form. J. Biol. Chem. 1997, 272, 6805-6811. [CrossRef] [PubMed]

50. Rybin, V.O.; Sabri, A.; Short, J.; Braz, J.C.; Molkentin, J.D.; Steinberg, S.F. Cross regulation of nPKC isoform function in cardiomyocytes: Role of PKCepsilon in activation loop phosphorylations and PKC $\delta$ in hydrophobic motif phosphorylations. J. Biol. Chem. 2003. [CrossRef]

51. Le Good, J.A.; Ziegler, W.H.; Parekh, D.B.; Alessi, D.R.; Cohen, P.; Parker, P.J. Protein kinase C isotypes controlled by phosphoinositide 3-kinase through the protein kinase PDK1. Science 1998, 281, 2042-2045. [CrossRef]

52. Stempka, L.; Schnölzer, M.; Radke, S.; Rincke, G.; Marks, F.; Gschwendt, M. Requirements of Protein Kinase C $\delta$ for Catalytic Function Role of Glutamic Acid 500 and Autophosphorylation on Serine 643. J. Biol. Chem. 1999, 274, 8886-8892. [CrossRef]

53. Kikkawa, U.; Matsuzaki, H.; Yamamoto, T. Protein kinase C $\delta$ (PKC $\delta$ ): Activation mechanisms and functions. J. Biochem. 2002, 132, 831-839. [CrossRef]

54. Zhao, M.; Xia, L.; Chen, G.-Q. Protein Kinase Cd in Apoptosis: A Brief Overview. Arch. Immunol. Ther. Exp. 2012, 60, 361-372. [CrossRef] 
55. Humphries, M.J.; Ohm, A.M.; Schaack, J.; Adwan, T.S.; Reyland, M.E. Tyrosine phosphorylation regulates nuclear translocation of PKC $\delta$. Oncogene 2007, 27, 3045. [CrossRef]

56. Pabla, N.; Dong, G.; Jiang, M.; Huang, S.; Kumar, M.V.; Messing, R.O.; Dong, Z. Inhibition of PKCd reduces cisplatin-induced nephrotoxicity without blocking chemotherapeutic efficacy in mouse models of cancer. J. Clin. Investig. 2011, 121, 2709-2722. [CrossRef]

57. Li, W.; Li, W.; Chen, X.-H.; Kelley, C.A.; Alimandi, M.; Zhang, J.; Chen, Q.; Bottaro, D.P.; Pierce, J.H. Identification of tyrosine 187 as a protein kinase C- $\delta$ phosphorylation site. J. Biol. Chem. 1996, 271, 26404-26409. [CrossRef]

58. Jackson, D.N.; Foster, D.A. The enigmatic protein kinase C $\delta$ : Complex roles in cell proliferation and survival. FASEB J. 2004, 18, 627-636. [CrossRef]

59. Pappa, H.; Murray-Rust, J.; Dekker, L.; Parker, P.; McDonald, N. Crystal structure of the C2 domain from protein kinase C- $\delta$. Structure 1998, 6, 885-894. [CrossRef]

60. Yamanashi, Y.; Mori, S.; Yoshida, M.; Kishimoto, T.; Inoue, K.; Yamamoto, T.; ToYOSHIMA, K. Selective expression of a protein-tyrosine kinase, p56lyn, in hematopoietic cells and association with production of human T-cell lymphotropic virus type I. Proc. Natl. Acad. Sci. USA 1989, 86, 6538-6542. [CrossRef]

61. Umemori, H.; Wanaka, A.; Kato, H.; Takeuchi, M.; Tohyama, M.; Yamamoto, T. Specific expressions of Fyn and Lyn, lymphocyte antigen receptor-associated tyrosine kinases, in the central nervous system. Mol. Brain Res. 1992, 16, 303-310. [CrossRef]

62. Yamada, E.; Pessin, J.E.; Kurland, I.J.; Schwartz, G.J.; Bastie, C.C. Fyn-dependent regulation of energy expenditure and body weight is mediated by tyrosine phosphorylation of LKB1. Cell Metab. 2010, 11, 113-124. [CrossRef]

63. Garcia, M.L.; Strehler, E.E. Plasma membrane calcium ATPases as critical regulators of calcium homeostasis during neuronal cell function. Front. Biosci. 1999, 4, D869-D882. [CrossRef]

64. Ahn, B.K.; Jeong, S.K.; Lee, S.H. Role of PKC- $\delta$ as a signal mediator in epidermal barrier homeostasis. Arch. Dermatol. Res. 2007, 299, 53-57. [CrossRef]

65. Voss, O.H.; Kim, S.; Wewers, M.D.; Doseff, A.I. Regulation of monocyte apoptosis by the protein kinase C $\delta$ (PKC $\delta$ )-dependent phosphorylation of caspase-3. J. Biol. Chem. 2005, 280, 17371-17379. [CrossRef]

66. Yoshida, K.; Liu, H.; Miki, Y. Protein kinase C $\delta$ regulates Ser46 phosphorylation of p53 tumor suppressor in the apoptotic response to DNA damage. J. Biol. Chem. 2006, 281, 5734-5740. [CrossRef]

67. Hu, Y.; Kang, C.; Philp, R.J.; Li, B. PKC $\delta$ phosphorylates p52ShcA at Ser29 to regulate ERK activation in response to H2O2. Cell. Signal. 2007, 19, 410-418. [CrossRef]

68. Lee, Y.-J.; Lee, D.-H.; Cho, C.-K.; Bae, S.; Jhon, G.-J.; Lee, S.-J.; Soh, J.-W.; Lee, Y.-S. HSP25 inhibits PKC $\delta$-mediated cell death through direct interaction. J. Biol. Chem. 2005, 280, 18108-18119. [CrossRef]

69. Disatnik, M.-H.; Boutet, S.C.; Lee, C.H.; Mochly-Rosen, D.; Rando, T.A. Sequential activation of individual PKC isozymes in integrin-mediated muscle cell spreading: A role for MARCKS in an integrin signaling pathway. J. Cell Sci. 2002, 115, 2151-2163.

70. Jideama, N.M.; Noland, T.A.; Raynor, R.L.; Blobe, G.C.; Fabbro, D.; Kazanietz, M.G.; Blumberg, P.M.; Hannun, Y.A.; Kuo, J. Phosphorylation specificities of protein kinase $\mathrm{C}$ isozymes for bovine cardiac troponin $\mathrm{I}$ and troponin $\mathrm{T}$ and sites within these proteins and regulation of myofilament properties. J. Biol. Chem. 1996, 271, 23277-23283. [CrossRef]

71. Churchill, E.N.; Murriel, C.L.; Chen, C.-H.; Mochly-Rosen, D.; Szweda, L.I. Reperfusion-induced translocation of $\delta$ PKC to cardiac mitochondria prevents pyruvate dehydrogenase reactivation. Circ. Res. 2005, 97, 78-85. [CrossRef]

72. Sawai, H.; Okazaki, T.; Takeda, Y.; Tashima, M.; Sawada, H.; Okuma, M.; Kishi, S.; Umehara, H.; Domae, N. Ceramide-induced Translocation of Protein Kinase C- $\delta$ and- $\epsilon$ to the Cytosol Implications in Apoptosis. J. Biol. Chem. 1997, 272, 2452-2458. [CrossRef]

73. Rybin, V.O.; Xu, X.; Steinberg, S.F. Activated protein kinase C isoforms target to cardiomyocyte caveolae: Stimulation of local protein phosphorylation. Circ. Res. 1999, 84, 980-988. [CrossRef]

74. Qi, X.; Mochly-Rosen, D. The PKC $\delta$-Abl complex communicates ER stress to the mitochondria-an essential step in subsequent apoptosis. J. Cell Sci. 2008, 121, 804-813. [CrossRef] 
75. Kajimoto, T.; Ohmori, S.; Shirai, Y.; Sakai, N.; Saito, N. Subtype-specific translocation of the $\delta$ subtype of protein kinase $\mathrm{C}$ and its activation by tyrosine phosphorylation induced by ceramide in HeLa cells. Mol. Cell. Biol. 2001, 21, 1769-1783. [CrossRef]

76. Gomel, R.; Xiang, C.; Finniss, S.; Lee, H.K.; Lu, W.; Okhrimenko, H.; Brodie, C. The localization of protein kinase $\mathrm{C} \delta$ in different subcellular sites affects its proapoptotic and antiapoptotic functions and the activation of distinct downstream signaling pathways. Mol. Cancer Res. 2007, 5, 627-639. [CrossRef]

77. Bhavanasi, D.; Badolia, R.; Manne, B.K.; Janapati, S.; Dangelmaier, C.T.; Mazharian, A.; Jin, J.; Kim, S.; Zhang, X.; Chen, X.; et al. Cross talk between serine/threonine and tyrosine kinases regulates ADP-induced thromboxane generation in platelets. Thromb. Haem. 2015, 114, 558-568. [CrossRef]

78. Song, J.S.; Swann, P.G.; Szallasi, Z.; Blank, U.; Blumberg, P.M.; Rivera, J. Tyrosine phosphorylation-dependent and-independent associations of protein kinase C- $\delta$ with Src family kinases in the RBL-2H3 mast cell line: Regulation of Src family kinase activity by protein kinase C- $\delta$. Oncogene 1998, 16, 3357. [CrossRef]

79. Zang, Q.; Lu, Z.; Curto, M.; Barile, N.; Shalloway, D.; Foster, D.A. Association between v-Src and protein kinase C $\delta$ in v-Src-transformed fibroblasts. J. Biol. Chem. 1997, 272, 13275-13280. [CrossRef]

80. Sun, X.; Wu, F.; Datta, R.; Kharbanda, S.; Kufe, D. Interaction between protein kinase C $\delta$ and the c-Abl tyrosine kinase in the cellular response to oxidative stress. J. Biol. Chem. 2000, 275, 7470-7473. [CrossRef]

81. Yoshida, K.; Kufe, D. Negative regulation of the SHPTP1 protein tyrosine phosphatase by protein kinase $C \delta$ in response to DNA damage. Mol. Pharmacol. 2001, 60, 1431-1438. [CrossRef]

82. Brodie, C.; Steinhart, R.; Kazimirsky, G.; Rubinfeld, H.; Hyman, T.; Ayres, J.N.; Hur, G.M.; Toth, A.; Yang, D.; Garfield, S.H. PKC $\delta$ associates with and is involved in the phosphorylation of RasGRP3 in response to phorbol esters. Mol. Pharmacol. 2004, 66, 76-84. [CrossRef]

83. Brandt, D.T.; Goerke, A.; Heuer, M.; Gimona, M.; Leitges, M.; Kremmer, E.; Lammers, R.; Haller, H.; Mischak, H. Protein kinase $\mathrm{C} \delta$ induces Src kinase activity via activation of the protein tyrosine phosphatase PTP $\alpha$. J. Biol. Chem. 2003, 278, 34073-34078. [CrossRef]

84. Uddin, S.; Sassano, A.; Deb, D.K.; Verma, A.; Majchrzak, B.; Rahman, A.; Malik, A.B.; Fish, E.N.; Platanias, L.C. Protein kinase $C-\delta($ PKC- $\delta$ ) is activated by type I interferons and mediates phosphorylation of Stat1 on serine 727. J. Biol. Chem. 2002, 277, 14408-14416. [CrossRef]

85. Jain, N.; Zhang, T.; Kee, W.H.; Li, W.; Cao, X. Protein kinase C $\delta$ associates with and phosphorylates Stat3 in an interleukin-6-dependent manner. J. Biol. Chem. 1999, 274, 24392-24400. [CrossRef]

86. Yuan, L.; Soh, J.-W.; Weinstein, I.B. Inhibition of histone acetyltransferase function of p300 by PKC $\delta$. BBA Mol. Cell Res. 2002, 1592, 205-211. [CrossRef]

87. Hamaguchi, A.; Suzuki, E.; Murayama, K.; Fujimura, T.; Hikita, T.; Iwabuchi, K.; Handa, K.; Withers, D.A.; Masters, S.C.; Fu, H. Sphingosine-dependent protein kinase-1 (SDK1), directed to 14-3-3, is identified as the kinase domain of PKC $\delta$. J. Biol. Chem. 2003, 278, 41557-41565. [CrossRef]

88. Novotny-Diermayr, V.; Zhang, T.; Gu, L.; Cao, X. Protein kinase C $\delta$ associates with the interleukin-6 receptor subunit glycoprotein (gp) 130 via Stat3 and enhances Stat3-gp130 interaction. J. Biol. Chem. 2002, 130, 49134-49142. [CrossRef]

89. Fontayne, A.; Dang, P.M.-C.; Gougerot-Pocidalo, M.-A.; El Benna, J. Phosphorylation of p47 p hox Sites by PKC $\alpha, \beta I I, \delta$, and $\zeta$ : Effect on Binding to p22 p hox and on NADPH Oxidase Activation. Biochemistry 2002, 41, 7743-7750. [CrossRef]

90. Alt, A.; Ohba, M.; Li, L.; Gartsbein, M.; Belanger, A.; Denning, M.F.; Kuroki, T.; Yuspa, S.H.; Tennenbaum, T. Protein kinase $\mathrm{C} \delta$-mediated phosphorylation of $\alpha 6 \beta 4$ is associated with reduced integrin localization to the hemidesmosome and decreased keratinocyte attachment. Cancer Res. 2001, 61, 4591-4598.

91. Siwko, S.; Mochly-Rosen, D. Use of a novel method to find substrates of protein kinase C $\delta$ identifies M2 pyruvate kinase. Int. J. Biochem. Cell Biol. 2007, 39, 978-987. [CrossRef]

92. Vidyasagar, A.; Wilson, N.A.; Djamali, A. Heat shock protein 27 (HSP27): Biomarker of disease and therapeutic target. Fibrogene. Tissue Repair 2012, 5, 7. [CrossRef]

93. Bharti, A.; Kraeft, S.-K.; Gounder, M.; Pandey, P.; Jin, S.; Yuan, Z.-M.; Lees-Miller, S.P.; Weichselbaum, R.; Weaver, D.; Chen, L.B. Inactivation of DNA-dependent protein kinase by protein kinase C $\delta$ : Implications for apoptosis. Mol. Cell. Biol. 1998, 18, 6719-6728. [CrossRef]

94. Murriel, C.L.; Churchill, E.; Inagaki, K.; Szweda, L.I.; Mochly-Rosen, D. Protein kinase C $\delta$ activation induces apoptosis in response to cardiac ischemia and reperfusion damage a mechanism involving Bad and the mitochondria. J. Biol. Chem. 2004, 279, 47985-47991. [CrossRef] 
95. Yogalingam, G.; Hwang, S.; Ferreira, J.C.; Mochly-Rosen, D. Glyceraldehyde-3-phosphate dehydrogenase $(\mathrm{GAPDH})$ phosphorylation by protein kinase $\mathrm{C} \delta(\mathrm{PKC} \delta)$ inhibits mitochondria elimination by lysosomal-like structures following ischemia and reoxygenation-induced injury. J. Biol. Chem. 2013, 288, 18947-18960. [CrossRef]

96. Liu, J.; Chen, J.; Dai, Q.; Lee, R.M. Phospholipid scramblase 3 is the mitochondrial target of protein kinase C $\delta$-induced apoptosis. Cancer Res. 2003, 63, 1153-1156.

97. Cross, T.; Griffiths, G.; Deacon, E.; Sallis, R.; Gough, M.; Watters, D.; Lord, J.M. PKC- $\delta$ is an apoptotic lamin kinase. Oncogene 2000, 19, 2331. [CrossRef]

98. Yoshida, K.; Wang, H.G.; Miki, Y.; Kufe, D. Protein kinase C $\delta$ is responsible for constitutive and DNA damage-induced phosphorylation of Rad9. EMBO J. 2003, 22, 1431-1441. [CrossRef]

99. Vancurova, I.; Miskolci, V.; Davidson, D. NF-kB activation in tumor necrosis factor $\alpha$-stimulated neutrophils is mediated by protein kinase C $\delta$. Correlation to nuclear IкB $\alpha$. J. Biol. Chem. 2001, 276, 19746-19752. [CrossRef]

100. Brown, K.A.; Brain, S.D.; Pearson, J.D.; Edgeworth, J.D.; Lewis, S.M.; Treacher, D.F. Neutrophils in development of multiple organ failure in sepsis. Lancet 2006, 368, 157-169. [CrossRef]

101. Aldridge, A.J. Role of the neutrophil in septic shock and the adult respiratory distress syndrome. Eur. J. Surg. 2002, 168, 204-214. [CrossRef]

102. Williams, A.E.; Chambers, R.C. The mercurial nature of neutrophils: Still an enigma in ARDS? Am. J. Physiol. Lung Cell. Mol. Physiol. 2014, 306, L217-L230. [CrossRef]

103. Reutershan, J.; Ley, K. Bench-to-bedside review: Acute respiratory distress syndrome-How neutrophils migrate into the lung. Crit Care 2004, 8, 453-461. [CrossRef]

104. Chou, W.H.; Choi, D.S.; Zhang, H.; Mu, D.; McMahon, T.; Kharazia, V.N.; Lowell, C.A.; Ferriero, D.M.; Messing, R.O. Neutrophil protein kinase $\mathrm{C} \delta$ as a mediator of stroke-reperfusion injury. J. Clin. Investig. 2004, 114, 49-56. [CrossRef]

105. Shukla, A.; Lounsbury, K.M.; Barrett, T.F.; Gell, J.; Rincon, M.; Butnor, K.J.; Taatjes, D.J.; Davis, G.S.; Vacek, P.; Nakayama, K.I.; et al. Asbestos-induced peribronchiolar cell proliferation and cytokine production are attenuated in lungs of protein kinase C- $\delta$ knockout mice. Am. J. Pathol. 2007, 170, 140-151. [CrossRef]

106. Ramnath, R.; Sun, J.; Bhatia, M. PKC $\delta$ mediates pro-inflammatory responses in a mouse model of caerulein-induced acute pancreatitis. J. Mol. Med. 2010, 88, 1-9. [CrossRef]

107. Chichger, H.; Grinnell, K.L.; Casserly, B.; Chung, C.S.; Braza, J.; Lomas-Neira, J.; Ayala, A.; Rounds, S.; Klinger, J.R.; Harrington, E.O. Genetic disruption of protein kinase C $\delta$ reduces endotoxin-induced lung injury. Am. J. Physiol. Lung Cell Mol. Physiol. 2012, 303, L880-L888. [CrossRef]

108. Wang, Y.; Roller, J.; Menger, M.D.; Thorlacius, H. Sepsis-induced leukocyte adhesion in the pulmonary microvasculature in vivo is mediated by CD11a and CD11b. Eur. J. Pharmacol. 2013, 702, 135-141. [CrossRef]

109. Roller, J.; Wang, Y.; Rahman, M.; Schramm, R.; Laschke, M.W.; Menger, M.D.; Jeppsson, B.; Thorlacius, H. Direct in vivo observations of P-selectin glycoprotein ligand-1-mediated leukocyte-endothelial cell interactions in the pulmonary microvasculature in abdominal sepsis in mice. Inflamm. Res. 2013, 62, 275-282. [CrossRef]

110. Reinhart, K.; Bayer, O.; Brunkhorst, F.; Meisner, M. Markers of endothelial damage in organ dysfunction and sepsis. Crit. Care Med. 2002, 30, S302-S312. [CrossRef]

111. Craciun, F.L.; Iskander, K.N.; Chiswick, E.L.; Stepien, D.M.; Henderson, J.M.; Remick, D.G. Early murine polymicrobial sepsis predominantly causes renal injury. Shock 2014, 41, 97-103. [CrossRef]

112. Soltoff, S.P. Rottlerin: An inappropriate and ineffective inhibitor of PKC $\delta$. Trends Pharmacol. Sci. 2007, 28, 453-458. [CrossRef]

113. Davies, S.P.; Reddy, H.; Caivano, M.; Cohen, P. Specificity and mechanism of action of some commonly used protein kinase inhibitors. Biochem. J. 2000, 351, 95-105. [CrossRef]

114. Moschos, S.A.; Jones, S.W.; Perry, M.M.; Williams, A.E.; Erjefalt, J.S.; Turner, J.J.; Barnes, P.J.; Sproat, B.S.; Gait, M.J.; Lindsay, M.A. Lung Delivery Studies Using siRNA Conjugated to TAT(48-60) and Penetratin Reveal Peptide Induced Reduction in Gene Expression and Induction of Innate Immunity. Bioconj. Chem. 2007, 18, 1450-1459. [CrossRef]

115. Begley, R.; Liron, T.; Baryza, J.; Mochly-Rosen, D. Biodistribution of intracellularly acting peptides conjugated reversibly to Tat. Biochem. Biophys. Res. Commun. 2004, 318, 949-954. [CrossRef] 
116. Goldenberg, N.M.; Steinberg, B.E.; Slutsky, A.S.; Lee, W.L. Broken Barriers: A New Take on Sepsis Pathogenesis. Sci. Transl. Med. 2011, 3, 88ps25. [CrossRef]

117. Maniatis, N.A.; Orfanos, S.E. The endothelium in acute lung injury/acute respiratory distress syndrome. Curr. Opin. Crit. Care 2008, 14, 22-30. [CrossRef]

118. Ley, K.; Reutershan, J. Leucocyte-endothelial interactions in health and disease. Handb. Exp. Pharmacol. 2006, 97-133.

119. Ley, K.; Laudanna, C.; Cybulsky, M.I.; Nourshargh, S. Getting to the site of inflammation: The leukocyte adhesion cascade updated. Nat. Rev. Immunol. 2007, 7, 678-689. [CrossRef]

120. Guo, R.-F.; Riedemann, N.C.; Laudes, I.J.; Sarma, V.J.; Kunkel, R.G.; Dilley, K.A.; Paulauskis, J.D.; Ward, P.A. Altered Neutrophil Trafficking During Sepsis. J. Immunol. 2002, 169, 307-314. [CrossRef]

121. Roth, N.M.; Kiani, M.F. A geographic information systems based technique for the study of microvascular networks. Ann. Biomed. Eng. 1999, 27, 42-47. [CrossRef]

122. Prabhakarpandian, B.; Wang, Y.I.; Rea-Ramsey, A.; Sundaram, S.; Kiani, M.F.; Pant, K. Bifurcations: Focal Points of Particle Adhesion in Microvascular Networks. Microcirculation 2011, 18, 380-389. [CrossRef]

123. Prabhakarpandian, B.; Pant, K.; Scott, R.; Patillo, C.; Irimia, D.; Kiani, M.; Sundaram, S. Synthetic microvascular networks for quantitative analysis of particle adhesion. Biomed. Microd. 2008, 10, 585-595. [CrossRef]

124. Rosano, J.; Tousi, N.; Scott, R.; Krynska, B.; Rizzo, V.; Prabhakarpandian, B.; Pant, K.; Sundaram, S.; Kiani, M. A physiologically realistic in vitro model of microvascular networks. Biomed. Microd. 2009, 11, 1051-1057. [CrossRef] [PubMed]

125. Tousi, N.; Wang, B.; Pant, K.; Kiani, M.F.; Prabhakarpandian, B. Preferential adhesion of leukocytes near bifurcations is endothelium independent. Microvasc. Res. 2010, 80, 384-388. [CrossRef]

126. Prabhakarpandian, B.; Shen, M.-C.; Pant, K.; Kiani, M.F. Microfluidic devices for modeling cell-cell and particle-cell interactions in the microvasculature. Microvasc. Res. 2011, 82, 210-220. [CrossRef]

127. Molla, M.; Panes, J.; Casadevall, M.; Salas, A.; Conill, C.; Biete, A.; Anderson, D.C.; Granger, D.N.; Pique, J.M. Influence of dose-rate on inflammatory damage and adhesion molecule expression after abdominal radiation in the rat. Int. J. Radiat. Oncol. Biol. Phys. 1999, 45, 1011-1018. [CrossRef]

128. Yuan, H.; Gaber, M.W.; McColgan, T.; Naimark, M.D.; Kiani, M.F.; Merchant, T.E. Radiation-induced permeability and leukocyte adhesion in the rat blood-brain barrier: Modulation with anti-ICAM-1 antibodies. Brain Res. 2003, 969, 59-69. [CrossRef]

129. Yuan, H.; Gaber, M.W.; Boyd, K.; Wilson, C.M.; Kiani, M.F.; Merchant, T.E. Effects of fractionated radiation on the brain vasculature in a murine model: Blood-brain barrier permeability, astrocyte proliferation, and ultrastructural changes. Int. J. Radiat. Oncol. Biol. Phys. 2006, 66, 860-866. [CrossRef] [PubMed]

130. Yuan, H.; Goetz, D.J.; Gaber, M.W.; Issekutz, A.C.; Merchant, T.E.; Kiani, M.F. Radiation-induced up-regulation of adhesion molecules in brain microvasculature and their modulation by dexamethasone. Radiat. Res. 2005, 163, 544-551. [CrossRef]

131. Flanders, K.C.; Ho, B.M.; Arany, P.R.; Stuelten, C.; Mamura, M.; Paterniti, M.O.; Sowers, A.; Mitchell, J.B.; Roberts, A.B. Absence of Smad3 induces neutrophil migration after cutaneous irradiation: Possible contribution to subsequent radioprotection. Am. J. Pathol. 2008, 173, 68-76. [CrossRef] [PubMed]

132. Francois, A.; Milliat, F.; Guipaud, O.; Benderitter, M. Inflammation and immunity in radiation damage to the gut mucosa. BioMed Res. Int. 2013, 2013, 123241. [CrossRef]

133. Wong, S.L.; Lau, C.W.; Wong, W.T.; Xu, A.; Au, C.L.; Ng, C.F.; Ng, S.S.M.; Gollasch, M.; Yao, X.; Huang, Y. Pivotal Role of Protein Kinase Cd in Angiotensin II-Induced Endothelial Cyclooxygenase-2 Expression: A Link to Vascular Inflammation. Arterioscl. Thromb. Vasc. Biol. 2011, 31, 1169-1176. [CrossRef] [PubMed]

(C) 2019 by the authors. Licensee MDPI, Basel, Switzerland. This article is an open access article distributed under the terms and conditions of the Creative Commons Attribution (CC BY) license (http:/ / creativecommons.org/licenses/by/4.0/). 